\title{
Correction to: Informal coercion during childbirth: risk factors and prevalence estimates from a nationwide survey of women in Switzerland
}

\author{
Stephan Oelhafen ${ }^{1 *}\left(\mathbb{D}\right.$, Manuel Trachsel $^{2,3}$, Settimio Monteverde ${ }^{2,4}$, Luigi Raio ${ }^{5}$ and Eva Cignacco ${ }^{1}$
}

\section{Correction to: BMC Pregnancy Childbirth 21, 369} (2021)

https://doi.org/10.1186/s12884-021-03826-1

Following publication of the original article [1], the authors identified an error in the author name of Eva Cignacco.

The incorrect author name is: Eva Cignacco Müller The correct author name is: Eva Cignacco

The original article [1] has been updated.

\section{Author details}

'Department of Health Professions, Applied Research \& Development in Midwifery, Bern University of Applied Sciences, Murtenstrasse 10, 3008 Bern, Switzerland. ${ }^{2}$ Institute of Biomedical Ethics and History of Medicine, University of Zurich, Zurich, Switzerland. ${ }^{3}$ Clinical Ethics Unit, University Hospital of Basel and Psychiatric University Clinics Basel, Basel, Switzerland. ${ }^{4}$ Department of Health Professions, School of Nursing, Bern University of Applied Sciences, Bern, Switzerland. ${ }^{5}$ Department of Obstetrics and Gynecology, University Hospital of Bern, Bern, Switzerland.

Published online: 22 June 2021

\section{Reference}

1. Oelhafen S, Trachsel M, Monteverde S, Raio L, Müller EC. Informal coercion during childbirth: risk factors and prevalence estimates from a nationwide survey of women in Switzerland. BMC Pregnancy Childbirth. 2021;21:369 https://doi.org/10.1186/s12884-021-03826-1.

The original article can be found online at https://doi.org/10.1186/s12884-

021-03826-1.

\footnotetext{
*Correspondence: stephan.oelhafen@bfh.ch

${ }^{1}$ Department of Health Professions, Applied Research \& Development

in Midwifery, Bern University of Applied Sciences, Murtenstrasse 10,

3008 Bern, Switzerland

Full list of author information is available at the end of the article
}

(c) The Author(s). 2021. Open Access This article is licensed under a Creative Commons Attribution 4.0 International License, which permits use, sharing, adaptation, distribution and reproduction in any medium or format, as long as you give appropriate credit to the original author(s) and the source, provide a link to the Creative Commons licence, and indicate if changes were made. The images or other third party material in this article are included in the article's Creative Commons licence, unless indicated otherwise in a credit line to the material. If material is not included in the article's Creative Commons licence and your intended use is not permitted by statutory regulation or exceeds the permitted use, you will need to obtain permission directly from the copyright holder. To view a copy of this licence, visit http://creativecommons.org/licenses/by/4.0/. The Creative Commons Public Domain Dedication waiver (http://creativeco mmons.org/publicdomain/zero/1.0/) applies to the data made available in this article, unless otherwise stated in a credit line to the data. 